Paideusis

\title{
Listening as a Teacher: Educative Listening, Interruptions and Reflective Practice
}

\section{Andrea English}

Volume 18, Number 1, 2009

URI: https://id.erudit.org/iderudit/1072340ar

DOI: https://doi.org/10.7202/1072340ar

See table of contents

Publisher(s)

Canadian Philosophy of Education Society

ISSN

0838-4517 (print)

1916-0348 (digital)

Explore this journal

Cite this article

English, A. (2009). Listening as a Teacher: Educative Listening, Interruptions and Reflective Practice. Paideusis, 18(1), 69-79.

https://doi.org/10.7202/1072340ar
Article abstract

In this inquiry, I ask what is distinctive about listening as a teacher. I develop the meaning of educative listening as a mode of listening to interruptions in a way that promotes students' thinking and learning. Interruptions in a teacher's listening are defined as any unexpected response from a student to the material presented - for example, a challenging viewpoint, a difficult question, or a confusing reply - that opens up possibilities for cultivating learning. To begin, I draw upon Dewey to examine the connections between listening and learning in teacher-student interaction. In the second section, I explicate the implications of Dewey's theory of learning for a theory of listening in reflective teaching. Here, I contend that reflective teaching entails educative listening. In the final section, I inquire into how teacher education can productively address the connections between learning to listen and learning to teach reflectively.
This document is protected by copyright law. Use of the services of Erudit (including reproduction) is subject to its terms and conditions, which can be viewed online.

https://apropos.erudit.org/en/users/policy-on-use/ 


\title{
Listening as a Teacher: Educative Listening, Interruptions and Reflective Practice
}

\author{
ANDREA ENGLISH \\ Mount Saint Vincent University, Canada
}

\begin{abstract}
In this inquiry, I ask what is distinctive about listening as a teacher. I develop the meaning of educative listening as a mode of listening to interruptions in a way that promotes students' thinking and learning. Interruptions in a teacher's listening are defined as any unexpected response from a student to the material presented - for example, a challenging viewpoint, a difficult question, or a confusing reply — that opens up possibilities for cultivating learning. To begin, I draw upon Dewey to examine the connections between listening and learning in teacher-student interaction. In the second section, I explicate the implications of Dewey's theory of learning for a theory of listening in reflective teaching. Here, I contend that reflective teaching entails educative listening. In the final section, I inquire into how teacher education can productively address the connections between learning to listen and learning to teach reflectively.
\end{abstract}

If we make the 'draft character' of good preparation clear enough to ourselves-for any planning of instruction can be only provisionally valid - then it is quite consistent to rate the instructional planning process highly, while at the same time recognizing that, in the end, each and every lesson holds in store a myriad of unforeseeable possibilities and that the openness of teachers' minds to new situations, impulses, and the difficulties arising from the moment is a criterion of their pedagogical competence.

— Wolfgang Klafki, 1958

The author Grace Paley remarks that it is useful for writers to have two ears, "one for literature, and one for home." A similar remark can be made about teachers. Teachers need two ears, one for teaching, and one for — well, everything else. The ear of the teacher presents itself when it is focused on cultivating learning. To say that listening is part of teaching is neither a surprising nor controversial statement. Most practicing teachers might say they do not have much of a choice but to listen in the varied situations that comprise their job. I will not attempt to discuss all the situations that arise in teaching practice. Rather, I would like to define the concept of educative listening as distinct from listening in non-teaching situations and to make clear the difference between the listening of the teacher and the listening of the student.

${ }^{1}$ Paley, 1994, p. $x$

(C) Copyright 2009. The author, Andrea English, assigns to Paideusis the right of first publication and educational and non-profit institutions a non-exclusive license to use this document for personal use and in courses of instruction provided that the article is used in full and this copyright statement is reproduced. Any other usage is probibited without the express permission of the author. 
Listening as a topic of educational philosophy has been largely overlooked until recently. ${ }^{2}$ In teaching, listening plays a vital role in helping the teacher gauge and understand the learning process of students. However, the educative aspect of listening can be taken for granted, not only by educational theorists, but by practicing teachers themselves. This is partly because experienced teachers tend to forget the learning process that went into figuring out how to skillfully and tactfully deal with the students' unexpected questions or unforeseeable responses. While the novice teacher may still consider unexpected responses as interruptions in their instruction, experienced teachers come to see these as part of the normal course of teaching, taking a (perhaps resigned) view of 'expect the unexpected.'

But such a view disguises the educative meaning of interruptions for all teachers. Interruptions in a teacher's listening, which I define as any unexpected verbal response from a student to the material presented-for example, a challenging viewpoint, a difficult question, or a confusing reply_open up unforeseeable possibilities for cultivating learning. In this inquiry, I develop the meaning of educative listening as a mode of listening to interruptions in a way that promotes students' thinking and learning. To begin, I draw upon Dewey to examine the connections between listening and learning in teacherstudent interaction. In the second section, I explicate the implications of Dewey's theory of learning for a theory of listening in reflective teaching. Here, I contend that reflective teaching entails educative listening. In the final section, I inquire into how teacher education can productively address the connections between learning to listen and learning to teach reflectively.

\section{Dewey on Listening in the Teacher-Learner Relation}

On the topic of teacher-student interaction, in Democracy and Education, Dewey writes, "the teacher is a learner and, without knowing it, the learner a teacher" (Dewey, 1916/1985, p. 167). While agreeing with Dewey's statement, I argue that this view of the teacher presupposes a certain understanding of teaching as a reflective practice, a notion which itself presupposes a certain understanding of how teachers listen. In other words, teachers who allow themselves to learn from their students are ones who listen to their students in a specific way.

To draw out the connections between listening and reflective teaching, we can first examine the role of listening in Dewey's early critique of the traditional model of instruction in The School and Society. Dewey's critique centers around defining the problems with the kind of teachers who view their job as imparting information for students to take in passively and recite back accurately when called upon (Dewey, 1907, p. 21f.; see also Dewey, 1916/1985). For Dewey, there is a direct connection between listening and learning that is assumed on this model of teaching: the student is expected to listen such that listening is nearly equated with learning. The traditional classroom setting with rows of desks and chairs facing forward is for Dewey symbolic of the type of learning that is based in passive listening to what one hears or reads and absorbing a series of pre-packaged truths determined to be important and worthwhile by the school board and teacher (Dewey, 1907, p. 21f). 'Listening' on this model means obeying and passively accepting the judgments of others, judgments concerning both the worthwhile content of instruction and also concerning what is deemed right and wrong in both epistemological and moral terms.

In the discussion that follows, I will refer to this type of teacher as the normative teacher in order to demonstrate how it can be distinguished from the concept of the reflective teacher. The normative teacher views learning as a standardized process leading to standardized forms of knowledge and skills.

2 See for example recent studies on dialogue and listening in educational contexts, Burbules/Rice, 1991, Garrison, 1996, Schultz, 2003, Haroutunian-Gordon, 2003 and 2009, Waks, 2008, and the volume on 'Listening and Reflection', edited by Leonard Waks, 2007, for contributions from many of these and other authors, including my own contribution, 'Interrupted Experiences: reflection, listening and negativity in the practice of teaching'. The present inquiry extends the notion of reflective teaching I develop therein. 
Dewey's assault on this traditional method of teaching, though political and moral in its implications, is grounded in a theory of learning. Dewey points out that what results from this type of normative teaching via the uniformity of curriculum and teaching methods is not the student's learning, but the "dependency of [his] mind upon another" (Dewey, 1907, p. 47f; see also Dewey, 1916/1985, p. 166f). In this way, the individual may be trained to repeat what he is told, but he will not truly learn in the sense of knowing how to evaluate the truth of what he is told, under what conditions it may be true, or why it is necessary or important.

On Dewey's notion of learning, learning is an individual process. People do not learn in a standardized way, and teaching processes which seek to mould learners so that they conform to oversimplified standards fail to see what is necessarily individual about every learning process. Since Dewey's writings, developments in understanding difference in education surrounding questions of race, gender, or religion and policies of inclusion, make it seem that teachers and other educators have made progress in recognizing the individuality and uniqueness of each learner. While recognition of these differences is important and vital in a democratic learning community, if we start from these categorizations to address difference in education, then there can be a tendency for teachers to categorize an individual prior to or independent of his or her learning process. The very prejudices sought to be redressed instead can be reinforced, an inversion of the initial intention. Rather than starting from external factors that characterize the individual, in his learning theory, Dewey is interested in the individualization of the learner that arises from within the personal learning process itself. ${ }^{3}$

To address the difference and otherness of learners that arise in their individual processes of transformation, Dewey develops the notion of learning as discovery. Learning as discovery seems to place emphasis on the active side of learning, in contrast to the passive model of learning he opposes. However, it would be a misconception only to understand his view as promoting the child's selfactivity, or simply "learning by doing," and thereby to overlook the passive component to his idea of learning. ${ }^{4}$ 'Discovery' implies not only finding something that is new and different, but also the 'undergoing' and 'suffering' that accompanies any encounter with the unfamiliar and unexpected (compare Dewey, 1916/1985, p. 147f.). Individuals do not learn when they are given pre-digested problems, or as Dewey calls them "ready-made problems"; rather, they learn when they find out what is difficult, confusing, or strange for them and inquire into what exactly is obstructing thought or action. Dewey seeks to point out that by recognizing that learning processes have the quality of a search to understand new and unfamiliar ideas or subject matter, we can recognize that learning processes necessarily involve a struggle: "Only by wrestling with the conditions of the problem at first hand, seeking and finding his own way out, does [the child] think. [...] If he cannot devise his own solution $[\ldots]$ and devise his own way out, he will not learn, not even if he can recite some correct answer with one hundred percent accuracy" (Dewey, 1916/1985, p. 167). For Dewey, all learning processes are coupled with this type of struggle, be it those of a child learning to read, a scientist making a new discovery in a lab, an artist working with new materials, or a teacher gaining new insight into his or her practice.

Dewey's idea that learning is necessarily accompanied by a struggle means that learning involves frustration, confusion, perplexity, and doubt on the part of the learner. This notion of learning is not new; it can be traced back through the traditions of educational philosophy. For example, in Plato's Meno, Plato describes the learning slave boy who attempts to answer Socrates' questions as disillusioned and perplexed about his own knowledge. Through this process the boy eventually is led to proclaim that he does not know. This initial admission of ignorance is a pre-condition for the boy's search for knowledge. Modern educational theory has also emphasized various forms of negativity in

\footnotetext{
3 The democratic import of Dewey's learning theory lies in its implications towards being open and tolerant towards difference (on these issues see Burbules/ Rice, 1991; Garrison 1996, Haroutunian-Gordon 2003).

${ }^{4}$ On this point, see English 2008.
} 
aesthetic, cognitive, and moral learning and experience. In Émile, Rousseau emphasizes that children necessarily experience perplexity and disillusionment in developing sense-perception (Rousseau, 1762/1979). Herbart (1806/1902) placed particular significance on the indispensability of the learner's struggle in the realm of moral learning. ${ }^{5}$

For Dewey, the experience of struggle as an experience of perplexity, frustration, or confusion is central to all realms of learning. Experiences such as frustration and doubt arise when our seemingly continuous stream of experience is interrupted due to our encounter with something new, unfamiliar, and thereby unexpected. Since learning necessarily involves movement towards the unfamiliar, all learning involves interruption when we experience something unanticipated that throws us off course. This experience of interruption is itself pre-reflective, but it can be transformed into a reflective aspect of experience if it is consciously and thoughtfully addressed and not ignored. In order for this transformation to take place, we first must recognize the interruption as pointing to a negativity of experience, something beyond the limits of our present knowledge and ability. Only then can we begin to ask ourselves, What happened? What went wrong? What might I need to change?

Dewey pulls apart this moment of perplexity in learning, demonstrating it as a productive and educative space of experience in which individuals are held in suspense; they can begin to inquire into and reflect upon themselves and the situation in which they are stuck. Reflection is a specific aspect of this process of inquiry that is important for both teachers and learners. It must be noted, however, that not all forms of thought qualify as reflection. In this context, reflection should be understood as the inquiring form of thinking that kicks in when we find ourselves in a state of doubt or mental difficulty, begin to understand that state, and search out the material that in some way will "resolve the doubt, settle and dispose of the perplexity" (Dewey 1933/1989, p. 121). Dewey views reflection as a means of dealing with the perplexities, difficulties, and frustrations that are constitutive of all learning processes. When reflection sets out to explain interruptions in our experience, it seeks to transform our modes of simply experiencing the world into processes of learning about the world and ourselves.

The moment of interruption in a learner's experience has educative meaning for the teacher. When a learner's experience is interrupted by stumbling upon something he doesn't understand, such as a word in a story he is reading, or something he is unable to do, such as drawing a horse in an art class, the teacher's experience is also interrupted. The learner's difficulty presents the teacher with a challenge as to how to address that learner's individual learning process. The reflective teacher addresses the learner's difficulty, seeing it as an opportunity for reflection on how to expand the learner's understanding and knowledge in order to deal with the given situation. ${ }^{6}$ In these moments, the reflective teacher asks, How can and should I proceed with teaching?

Dewey provides some insight into how the learner's listening changes on this model of reflective teacher-learner interaction. Instead of listening to obey, learners listen with a desire to learn, in order to seek the answer to questions that arise when their experiences do not meet their anticipations and they do not see a way out of their difficulties (Dewey, 1907). ${ }^{7}$ As Dewey points out, it is only through participation in the world and communication with others that learners find out what is difficult or challenging for them personally. ${ }^{8}$ Teacher-learner interaction involves facilitating and cultivating moments for learners to find out for themselves wherein their difficulties lie, where their blind spots are, where their abilities and knowledge need expansion. But how can we describe the

\footnotetext{
5 In this context, the term 'negative' is not meant in a pejorative sense, nor does it necessarily refer to something unpleasant. Rather, it is a constitutive part of the process of learning itself. On the concept of negativity in the traditions of educational philosophy see Benner 2003, Benner/English 2004. On the notions of interruption and negativity of experience in reflective teaching with particular reference to Dewey, see English 2005 and 2007a and 2007b. See also Buck 1981 and Meyer-Drawe 1984.

${ }^{6}$ This points to the two-fold nature of the negativity of experience in teaching see Benner/English, 2004.

${ }^{7}$ See also Haroutunian-Gordan, 2003, on listening and questioning in dialogue across difference.

${ }^{8}$ On this point see also Garrison 1996.
} 
teacher's listening in this type of teacher-learner interaction? Although Dewey addresses to a certain extent how the learner's listening changes in the transition from a traditional method of learning to his model of reflectively learning by discovery, he says little about the implications of his model for the teacher's listening. In the next section, I seek to draw out these implications in order to develop a notion of how the reflective teacher listens and how this relates to understanding the teacher as a learner.

\section{Listening to Learn — Listening as a Reflective Teacher}

The reflective teacher, first and foremost, is open to the idea of learning from the teacher-student interaction. This openness is characterized by the teacher's openness to new and unexpected situations; that is, to considering the interruptions in the learner's experiences as points of departure for innovative thinking about improving teaching practice. When these interruptions are mediated by listening, they come forth for the teacher in classroom discussion as unexpected responses, contradictory viewpoints, confusing replies, or difficult questions the teacher is not prepared to answer. Educative listening in this context can be defined as being attuned to and engaging with interruptions in order to determine how they suggest new ways of initiating the learning processes of others.

There are various ways a teacher might be listening to interruptions without the educative quality of listening. I would like to look at three such problematic modes of listening in teaching that lack the educative aspect of listening. Following this, I will examine how educative listening manifests itself in reflective teaching. The examples of listening below do not cover all possible ways of listening in teaching, but they are common to many teachers and can occur in teaching any subject matter to any age group. Here, I illustrate the dynamics of listening using a teacher-student interaction that might occur in third grade arithmetic instruction.

To begin, we can look at the type of listening that occurs when a teacher asks such general questions that we can scarcely determine what qualifies as an interruption in the teacher's listening. If a teacher, for example, wants to teach the relation between multiplication and addition, she might write an example on the board such as, " $5 \times 5=5+5+5+5+5$," and then ask the class, "Are there any questions?" The teacher's question is too general, such that it invites either no response at all from students, or invites questions unrelated to the material, such as "Can we play a game?" In this case, a teacher is open to all kinds of responses from the students, but is not able to listen in such a way that connects the students' inquiries to what she is trying to teach. The teacher's questioning and listening are not of a sort that initiates learning in others. For this teacher, all responses from students are equally expected and unexpected and therefore can be hardly classified as interruptions. The teacher lacks an ability to listen within a certain horizon of expectations and thus lacks the ability to anticipate how the students might respond to the lesson at hand.

A second problematic mode of listening in teaching is listening as a means of mechanically filtering right and wrong answers. This type of listening can be attributed to normative teaching. As discussed above, teaching for the normative teacher is largely characterized by the motto "the teacher teaches, the student learns," which generally amounts to "the teacher speaks, the student listens." Dewey makes a brief remark about this type of listening when he writes that in traditional models of instruction, the teacher provides "ready-made subject matter and listens to the accuracy with which it is reproduced" (Dewey, 1916/1985, p. 167). For example, the teacher may didactically present the 5's of the multiplication tables on the board and then ask the class "what is $5 \times 5$ ?" If a student's answer is "10," it is deemed as wrong and the teacher only continues listening until a student arrives at the right answer. This framework for a teacher's questions is reserved for confirming apprehension, so that interruptions such as differences of opinion or unexpected responses in the classroom are classified negatively as lack of understanding and 'wrong answers.' In this context, interruptions inform the teacher about the learning student, but not about the practice of teaching. Thus, a normative mode of 
teaching does not understand teaching as a dialogue between teacher and student, and this mode of listening does not further the students' learning.

Whereas in normative teaching all interruptions are heard as wrong answers, a teacher might also listen to hear interruptions as 'right answers.' In this third problematic mode of listening, the teacher's listening is focused on finding ways to reconfigure students' unexpected responses into continuities with the planned lesson. For example, if a student responds with "10" to the question "who knows what 5 times 5 equals?" then the teacher may reply by saying, "Yes, that's true, if we're asking, what 5 plus 5 equals," and then repeat the original question. While this teacher has a clear direction for her lesson and seeks to guide students in that direction, her listening is reserved for changing what she actually hears to conform to what she wants to hear. The potentially educative discontinuity of the interruption is subsumed into an overarching continuity with the lesson. In the end, while teachers who listen in this way may value encouraging students' thought, they ultimately shade over the differences between what they want to teach and what the students know or want to learn. In the process, the interruption is not a guide to transforming the teacher's practice because the uniqueness of the student's contribution is overlooked. The learners may feel encouraged by this teacher, but they are ultimately not learning the similarities and differences in forms of knowledge, because the teacher is not pointing them out. ${ }^{9}$ Since everything students say is woven into a continuity of the planned lecture, the teacher is only truly interrupted when students' questions and responses are so unexpected that they do not fit into the lesson at all, leaving the teacher at a complete loss for how to proceed.

What is different about how the reflective teacher listens to interruptions? For the reflective teacher, interruptions in listening are the heart of the educational matter. Interruptions point out the differences in the ways of thinking between the teacher and students and between the different students in the classroom. The reflective teacher does not listen normatively as a mechanical filter for right and wrong answers, nor seeks to transform all answers into right ones. Rather, the reflective teacher asks questions to cultivate the learners' struggle with understanding the material, and listens to see if this struggle is taking place. So what might this type of questioning and listening look like? If we take the above example, we can imagine a dialogue between teacher and students that shows how the reflective teacher might guide his or her class through the material differently than the other teachers described. The dialogue could look something like this:

Teacher: "Who can tell me what 5 times 5 equals?"

Student 1: "10."

Teacher: “OK, how do we get to 10 ? How many 5's are there in ten?"

Student 2: "2."

Teacher: “OK, so if we take two 5's and add them together, ' $5+5=10$,' right?”

The students understand addition and have no objections.

Teacher: "So how many 5's do we need to add together in 5 times 5?"

Student: "5."

Teacher asks student to write it out on the board and add them together: $5+5+5+5+5$ $=25$.

Teacher: "Good. So 5 times $5=25$. Now let's go back to look at the number 10 . We said $5+5$ is 10 ; that's 5 times what number equals 10 . Can anyone tell me what number is missing?"

\footnotetext{
" On the idea of teaching as "pointing out" see Prange, 2005.
} 
Of course there are many possible questions and answers that could lead to a different conversation, depending on what level of knowledge the students already have and depending on whether there are specific right or wrong answers to the questions at hand. The significance of this example is that the teacher expected that the students would be able to answer the first question about multiplication, but when an unexpected and, in this case, wrong answer is heard, it is drawn upon to explore connections between what the students already had learned and what she was trying to teach them. The teacher thereby shows the students ways of understanding the connections between addition and multiplication, but also the differences between these two ways of doing math.

Independent of the subject matter, reflective teaching involves working out the student's frustration and difficulties dialogically. For the reflective teacher, helping the students discover the similarities and differences between what they know and what they still can learn is a process that involves listening to see if students are thinking beyond what they already know and thus trying to grasp something new. By listening to the students the reflective teacher is implicitly asking herself, "What do I need to hear so that I know that thinking and learning are taking place?" The answer to this question is never straightforward, regardless of the subject matter. It is a difficult task in teaching to decipher whether or not a student is really thinking about the material. The teacher might wonder, Did the student give me a right answer because she is repeating what she read in the book or does she really understand? Is the student's wrong answer just an arbitrary guess, or is she really trying to grasp the material?

The reflective teacher seeks to listen between right and wrong answers, in the "gray zones" of students' thinking and learning that are revealed in the interruption. While the reflective teacher can anticipate certain potential answers due to her knowledge of the level of her students, at the same time she understands that she can never know exactly what to expect from learners' responses. She allows the unexpected responses to interrupt in an educative way that causes her to hesitate, suspend judgment and become perplexed by what she hears. As Sophie Haroutunian-Gordan explains, interruptions in listening are central to the process of changing one's beliefs in dialogue with others who have differing beliefs and "the nature of the interruption determines the direction of the shift in subsequent listening" (2003, p. 13). ${ }^{10}$ Genuine interruptions signal blind spots in a teacher's own thought and knowledge that make her consider a perspective she has never considered before. ${ }^{11}$ When the teacher becomes aware of her own blind spot through a student's question or response in classroom interaction, then the teacher learns and the student is, as Dewey put it, "without knowing it, a teacher" (Dewey 1985 [1916], p. 167).

When a teacher is attuned to interruptions, she is listening to the otherness and difference of the learner. This process of teacher-student dialogue is transformative insofar as both teacher and learner begin to hear how they are being heard by each other, and they can seek out ways of learning from one another. Nicholas Burbules and Suzanne Rice make an illuminating point about all dialogue across difference, one that I see as essential for understanding any educative teacher-student dialogue: "as a process, dialogue requires us to re-examine our own presuppositions and to compare them against quite different ones; to make us less dogmatic about the belief that the way the world appears to us is necessarily the way the world is" (Burbules \& Rice, 1991, p. 405; see also Laverty 2007). When teachers hear that there is a gap between how they are being heard by their students and how they want to be heard, they begin to listen inside themselves, to hear how their instruction changes in light of what they hear. By listening to ourselves as teachers, we become aware of the process of teaching and aware of the fact that we can decide to change it.

\footnotetext{
${ }^{10}$ See also Haroutunian-Gordan, 2007 and Waks, 2007. See also Schultz's (2003) study on listening and how teachers can create listening communities in classrooms in which teachers listen to students and students begin to listen and learn from each other.

${ }^{11}$ On this point see Meyer-Drawe, 1987.
} 


\section{Learning to Listen and Teacher Education}

Teacher educators generally accept that dialogue and discussion are to be part of any future teachers' classroom. As teacher education programs have moved away from understanding teaching as transmission, they expect pre-service teachers to learn to teach in such a way that initiates dialogue and discussion in young learners. This implies that if learners are to engage in discussion in classroom learning and not become passive listeners, then teachers must learn how to differentiate what they hear and understand how a student's response relates to how that particular student is thinking about the subject matter.

In his early essay on listening, William Hare (1975) cautions educational theorists to resist the temptation to believe that listening is something people do naturally and thus to assume that it does not require special attention. As he points out, when we refer colloquially to someone as a "good listener" this does not simply refer to one who conforms to what is heard, or one who accepts what he hears uncritically. Rather, being a good listener involves judgment of what is heard and knowledge of "how to take things and what to listen for" (Hare, 1975, p. 9). This type of knowledge and judgment must itself be learned. Hare's discussion of the good listener makes clear that a certain interrelationship must exist between the listener and the speaker in order for listening to be generative for both. According to Hare, a good listener is one who is open-minded and willing to listen to the ideas and thoughts of the other person in such a way that allows those ideas heard to potentially change the way the listener thinks (Hare 1975; see also Hare 1983). For teachers to begin to understand themselves as critical, reflective, educative listeners, they must first understand to become open to learning within the teacher-learner relation.

For prospective teachers to learn to listen in such a way that, through their listening, they are figuring out the limits of the student's knowledge and ability as well as their own, they have to learn to understand that listening involves becoming open to another person and to new ideas. As Jim Garrison points out, the openness required for listening involves taking a risk and becoming vulnerable: "Remaining open is awkward. We must be willing to live with confusion and uncertainty about both ourselves and the other person we are attempting to understand" (Garrison, 1996, p. 433). An essential part of what it means to be a teacher is learning how to take this risk and in the process to begin to define yourself in terms of the other, the learner.

Teacher education must guide pre-service teachers to transform their notion of 'teaching as telling' to one of 'teaching as questioning, listening, and pointing out.' Philosophy of education can contribute to this process significantly, not only by helping prospective teachers come to a theoretical understanding of educative listening, but also by helping them connect theories of listening to their own teaching practice. This process could begin by first having prospective teachers prepare a lesson plan on a philosophical text to teach in a class discussion. This preparatory phase serves to help the particular student create expectations about how the class discussion might unfold. Prospective teachers often have difficulty with creating open questions. Their lesson planning will often amount to didactically listing a series of important points to cover with few questions. To address this, in a second phase, the student could discuss her plans with the teacher educator, who can help her transform her lesson plan into open questions that can guide classroom dialogue. The transformed lesson plan can serve as a guide for creating expectations about what she will hear in the context of classroom discussion about a particular subject matter. Teacher educators can facilitate this transformation because they listen differently than the student and have developed different expectations about what might be heard in the discussion. In a third phase, the student can then be given the opportunity to test the transformed lesson plan by teaching the text to classmates while remaining open to the fact that expectations may be defied by unanticipated responses. In a concluding phase, the student can take account of the interruptions that occurred in the practice of listening and use these again to transform her questions and expectations anew. Through this process, prospective teachers not only can become aware of the fact that lesson planning is a dynamic process - one that involves taking account of the 
learning individuals in the classroom - but they can also learn of their own expectations and how these are not static, but rather flexible and transformable. ${ }^{12}$

As teachers become more experienced in teaching their subject, they begin to expand their expectations by gauging the types of responses or confusions students typically have. Of course, no teacher can ever fully know what to expect from students, and when expectations become fixed they can serve as a hindrance rather than a help to education. An example of this is found when school policymakers and teachers make generalizations such as correlating genders or ethnic backgrounds with the potential to excel or fail in a particular subject. Such generalizations diminish the possibilities of reflective teaching that seeks ways in which students defy expectations and continue to make unique and innovative contributions to their own learning processes.

\section{Conclusion}

One might ask, Are there times in teaching when correction of error takes precedence over listening, such that a return to normative teaching is justified? The fact remains that the normative teacher fails to see that the method of correcting error does not necessarily achieve the desired result, namely the student's changed belief. The reflective teacher recognizes that correction of error is vital, but also that the method by which a teacher corrects the student is directly related to how and whether or not the student learns. Reflective teaching entails listening to students in a way that is open to interruptions; it deals with these productively by incorporating them into the students' learning processes such that the students begin to understand and question why they believe what they believe.

Teacher education must find ways to open up, pull apart and make explicit the space of interruptions in teaching that do not affect experienced teachers in the same way they can affect novice teachers. By making this process explicit, teacher education programs can come to recognize the specific difficulties involved in learning to listen and learning to teach. Thereby, pre-service teachers can begin to understand, as Wolfgang Klafki puts it, the "draft character" of planning and preparation for classroom situations.

The "blind spots" of practice and experience are not something we can ever fully avoid. Certainly it would not be Dewey's intention to say that mastery of reflective thinking can lead to mastery over the unexpected and unknown. Rather, these blind spots are to be cherished; they remind us that we cannot fully foresee the future. They are what keep us humble and reveal to us that we are only human and cannot know everything. It would be a dire situation if we could know everything and foresee the future such that there were no surprises and no interruptions, which in turn would mean no innovation, no need for exploration. A society that claimed to have all the answers so that we could all stop looking would not be a democratic pluralistic society but one that had fallen into the clutches of dogmatism. In the words of Hannah Arendt, "Our hope always hangs on the next generation; and

\footnotetext{
${ }^{12}$ In my research on listening, I incorporated these phases into an advanced philosophy of education seminar, cotaught with Dietrich Benner, on 'Childhood, Youth, and Adulthood', designed for pre-service teachers and educators in the Philosophy of Education Section of the teacher education program at Humboldt University Berlin. I interviewed five participating students individually before and after the process to understand their expectations and how these changed. Two questions were particularly informative in the interview conducted after the final stage of this process. I asked the student to reflect first on what changed from her initial instructional planning for the class discussion and her transformed lesson plan and secondly, to reflect on the difference between what answers to her questions she expected to hear from her classmates and what answers they actually gave. This reflective phase in journaling or discussion could be used as a closing phase to the process to help students become aware of their own learning process and begin to see connections between learning to listen and learning to teach. The interview questions were informed by Wolfgang Klafki's notion of instructional planning; see Klafki, 1958/2000. Special thanks to Dietrich Benner and the participating students.
} 
because our hope is based on this alone, we destroy everything if we try to control the new such that we, the old, can dictate how it will look" (1958/1997, p. 192). Teacher education can and must help prospective teachers understand how to reflectively deal with the difficulty inherent in their practice, a difficulty intimately tied to the fact that teachers have to acquaint the next generation with the world as it is, while preparing them for a future yet to be discovered.

\section{Acknowledgments}

Parts of this paper were first presented at the American Educational Research Association Annual Meeting, March 2008, on the panel "Listening to Learn-Learning to Listen" and at the scholarly conference on "Open-mindedness and the Virtues in Education," October, 2008.

\section{References}

Arendt, H. (1958/1997). The Crisis in Education. In Between Past and Future. Eight Exercises in political Thought (pp. 173-196). Harmondsworth: Penguin.

Benner, D. (2003). Kritik und Negativität. Ein Versuch zur Pluralisierung von Kritik in Erziehung, Pädagogik und Erziehungswissenschaft. Zeitschrift für Pädagogik. 46, p. 96-110.

Benner, D./English, A. (2004). Critique and Negativity: Toward the Pluralisation of Critique in Educational Practice, Theory and Research. Journal of Philosophy of Education, 38 (3), 409-428.

Buck, G. (1981): Negativität, Diskontinuität, und die Stetigkeit des Bios. In G. Buck (Ed), Hermeneutik und Bildung (pp. 71-94). München: Fink.

Burbules, N., \& Rice, S. (1991). Dialogue Across Difference: Continuing the Conversation. Harvard Educational Review 61 (4). 393-416.

Dewey, J (1907). The School and Society. The Middle Works. Vol. 1. Carbondale: SUP.

Dewey, J. (1916/1985). Democracy and Education. The Middle Works. Vol. 9. Carbondale: SUP.

Dewey, J.(1933/1989). How We Think. The Later Works. Vol. 8 (pp. 105-352). Carbondale: SUP.

English, A. (2005). Negativity and the New in John Dewey's Theory of Learning and Democracy: Towards a Renewed Look at Learning Cultures. Zeitschrift für Eræiiehungswissenschaft. 8 (1), 28-37.

English, A. (2007a). Interrupted Experiences: Reflection, Listening and Negativity in the Practice of Teaching. Learning Inquiry, L. Waks. (Ed). Special Issue on Reflection and Listening, 1(2), 133-142.

English, A. (2007b). Die experimentelle Struktur menschliches Lehren und Lernen: Ein Versuch über die Rolle negativer Erfahrung in den Lehr-Lerntheorien von Herbart und Dewey. In R. Bolle and G. Wiegand (Eds.) Johann Friedrich Herbart: 200 Jahre Allgemeine Pädagogik. Wirkungsgeschichtliche Impulse. (pp. 97-112) Münster:Waxmann Verlag.

English, A (2008). 'Wo 'doing' aufhoert und 'learning' anfingt : John Dewey über Lernen und die Negativität im Erfahrung und Denken,' in K. Mitgutsch, E. Sattler, K Westphal, IM Breinbauer (Eds.), Dem Lernen auf der Spur (pp.145-158). Klett-Cotta: Stuttgart.

Garrison, J. (1996). A Deweyan Theory of Democratic Listening. Educational Theory, 46(4), pp. 429-451.

Hare, W. (1975). Has Listening had a Fair Hearing? Agora (3) 1-2, pp. 5-13.

Hare, W. (1983). Open-mindedness and Education. Kingston: McGill-Queen's UP.

Haroutunian-Gordon, S. (2003). Listening - In a Democratic Society. Philosophy of Education, pp. 1-18.

Haroutunian-Gordon, S. (2007). Listening and Questioning. Learning Inquiry, L. Waks. (Ed). Special Issue on Reflection and Listening, 1(2), 143-152.

Haroutunian-Gordan, S. (2009). Learning to teach Through Discussion: The Art of Turning the Soul, Yale University Press.

Herbart, J.F. (1806/1902). The Science of Education, Henry and Emmie Felkin (Trans.) Boston: D.C. Heath \& Co. 
Klafki, W. (1958/2000). Didaktik Analysis as the Core of Preparation of Instruction. In Ian Westbury, Stefan Hopmann, Kurt Riquarts (Eds,) Teaching as a reflective practice: The German Didaktik Tradition. Mahwah: Lawrene Erlbaum Associates. Pp. 139-160.

Laverty, M. (2007). Dialogue as Philosophical Inquiry in the Teaching of Sympathy and Tolerance. Learning Inquiry, L. Waks. (Ed). Special Issue on Reflection and Listening, 1(2), pp. 125-132.

Meyer-Drawe, K. (1984). Lernen als Umlernen - Zur Negativität des Lernprozesses. In: W. Lippitz and K. Meyer-Drawe (Eds).Lernen und seine Horizonte. Phänomenologische Konzeptionen menschlichen Lernens - didaktische Konsequenzen, Scriptor, Frankfurt am Main. Pp. 19-45.

Meyer-Drawe, K (1987). Die Belehrbarkeit des Lehrenden durch den Lerneden - Fragen an den Primat des Pädagogischen Bezugs, In W. Lippitz and K. Meyer-Drawe (Eds). Kind und Welt: Phänomenologische Studien zur Pädagogik. Frankfurt am Main: Athenaeum Verlag.

Paley, G. (1994). The Collected Stories. New York: Farrar, Straus and Giroux.

Plato. Meno. (W.R.M. Lamb, Trans.). Vol. II. London: William Heinemann Ltd.

Prange, K. (2005). Die Zeigestruktur der Erziehung. Grundriss der operativen Pädagogik. Paderborn: Ferdinand Schöningh.

Rousseau, J.J. (1762/1979). Emile or On Education. (A. Bloom, Trans.). New York: Basic Books. Schultz, K (2003). Listening: A Framework for Teaching Across Difference. New York: Teachers College Press.

Waks, L.J. (2007). Listening and Questioning. The Apophatic/cataphatic Distinction Revisited. Learning Inquiry, Special Issue on Reflection and Listening 1 (2), 153-161.

Waks, L.J. (2008). Listening from Silence. Inner Composure and Engagement. Paideusis. 17 (2). 65-74.

\section{About the Author}

Andrea English is an Assistant Professor in the Department of Education at Mount Saint Vincent University, Halifax, Canada. She received her PhD from Humboldt University, Berlin, Germany. Her research focuses on theories of teaching and learning, the concept of negativity in education, John Dewey, J. F. Herbart and continental educational philosophy. Her work has been published in international scholarly philosophy of education journals, such as Journal of Philosophy of Education and Zeitschrift für Pädagogik and she has been an invited contributor to a number of edited books.

Web: http://www.msvu.ca/education/faculty/AEnglish.asp

Email: andrea.english@msvu.ca 